\title{
Kasvatus työssä
}

A

ikuiskasvatuksesta vaikuttaa viime vuosina tulleen aikaisempaa paljon muodikkaampi. Tämä ei ole yllättävää. Jos lukee esimerkiksi mitä tahansa Euroopan talouskasvun takaamiseen tähtääviä strategiaohjelmia, huomaa nopeasti, että keskeinen iskusana on elinikäinen oppiminen. Esimerkiksi EU:n komission viime syksynä julkaisemassa Työoikeuden vihreässä kirjassa "Työlainsäädäntö 2000-luvun haasteiden tasalle" elinikäistä oppimista korostetaan oike-

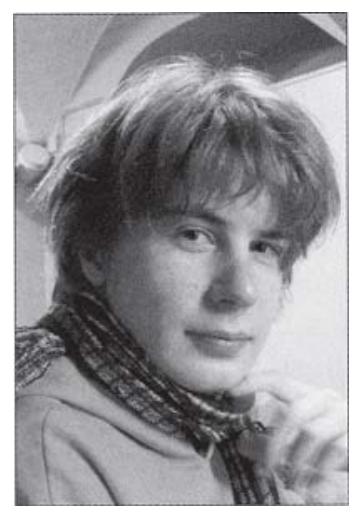

minen työhön ei kuitenkaan suju ilman ristiriitoja. Tuotantotaloutta opiskeleva meksikolainen ystäväni sanoi suoraan, että kyse on "ihmisen riistämisestä ihmisen avulla”. Pelissä on kuitenkin ihmisten elämä, haluineen, tuntemuksineen ja ajatuksineen, joita on vaikea mitata puhtaasti taloudellisin kriteerein tai alistaa kokonaan taloudellisille vaatimuksille. Henkilökohtaisen elämän hyväksikäytöstä huolimatta palkkaa maksetaan vain tietyistä suorituksisastaan enemmän kuin mitään työlainsäädäntöön kuuluvia tekijöitä.

Ihmisten oppimiskyvyn ja sosiaalisten suhteiden järjestelystä on tullut taloudellisen kasvun tärkein lähde. Ja aikuiskasvatuksen kohteenahan on ihmisen elämän kokonaisuus, aivot ja ruumis ja hänen suhteensa toisiin ihmisiin. Ihmisen aivoihin ja ruumiiseen sisältyvät sekä hänen käyttämänsä työkalut että niiden käyttämiseen vaadittavat erityiset taidot ja kokemus. Lähes kaikilla nousevilla tuotannonaloilla asiakaspalvelusta henkilöstöjohtamiseen työ vaatii persoonallisuuden laittamista likoon.

Viime aikoina on keskusteltu paljon myös siitä, että yritykset haluaisivat enemmän naisia johtotehtäviin. Kyse ei ole pelkästä tasa-arvokysymyksestä vaan siitä, että nykyaikainen johtaminen vaatii sellaisia taitoja, joita on perinteisesti pidetty naisille ominaisina ja joita esimerkiksi tyttöjen kasvatuksessa on korostettu. Ne ovat myös taitoja, jotka perinteisesti kuuluivat naisvaltaisille työvoiman uusintamiseen liittyville aloille kuten opetukseen ja kasvatukseen. Henkilöstöjohtaminen voidaankin käsittää eräänlaisena "hoivatyön" parhaiten palkattuna sektorina. Ylipäätään yrityksille on siis tärkeää valjastaa käyttöönsä taitoja, jotka ovat kehittyneet ihmisten koko elämän myötä ja syntyneet yrityksistä riippumatta.

Kaikkein eniten kiinnostusta herättävätkin nykyään juuri ihmisten johtamiseen liittyvät alat: kauppatieteet, tuotantotalous, aikuiskasvatus. Sveitsiläisen taloustieteilijän Christian Marazzin sanoin nykytaloudessa olennaista on "ihmisen tuottaminen ihmisen avulla”. Kaikkien ihmissuhteiden ja henkilökohtaisten ominaisuuksien laittata. Eikä niin sanottu työn feminisoituminen ole korjannut sukupuolten välisiä palkkaeroja millään tavoin.

Ja niin paljon kuin innovatiivisuutta nykyisin korostetaankin, ei työnantajien välittömistä vaatimuksista riippumattomalle luovalle ajankäytölle haluta antaa mahdollisuuksia. Vaikka elinikäisestä oppimisesta puhutaan kaikkialla, yritetään pääsyä koulutukseen rajoittaa yhä enemmän.

Nähdäkseni hyvän elämän eläminen nykyaikaisessa yhteiskunnassa edellyttää mahdollisuutta hallita itse omaa elämäänsä ja kehittyä vapaasti ilman, että on joka käänteessä alistuttava esimerkiksi ailahtelevaisilta osakemarkkinoilta tuleviin vaatimuksiin.

Sen takaamiseksi tarvitaan kaksi yhteiskunnallista perusvaatimusta. Ensimmäinen on ilmainen, kaikkien saatavilla oleva laadukas koulutus. Toinen on perustulo, joka on riippumatonta palkkatyöstä ja siten takaa mahdollisuuden aitoon elinikäiseen oppimiseen.

EETU VIREN

Vuosi sitten toukokuussa tuolloin 25-vuotias Helsingin yliopiston kirjallisuuden opiskelija ja prekariaattiaktivisti päästi TV-keskustelussa suustaan ruman sana, "paskaduuni" tarkoittaen huonosti palkattuja hommia surkein työehdoin. Aikuiskasvatus-lehdessä hän ei kuitenkaan halunnut jatkaa enää paskaduunikeskustelua. Kooste siitä löytyy osoitteesta: http://www.ylioppilas/ehti.fi/2006/09/08/passiivinenaktivisti/ 